\title{
ジェットポンプの性能に及ぼすスロート内表面粗さの影響*
}

\author{
山崎之崇*1, 中山智 理*1, 奈良林 直*2 \\ 小 林 秀 壽*3, 社河内 敏彦*1
}

\section{Effect of Throat Surface Roughness on Jet Pump Performance}

\author{
Yukitaka YAMAZAKI, Tomonori NAKAYAMA, Tadashi NARABAYASHI, \\ Hidetoshi KOBAYASHI and Toshihiko SHAKOUCHI*4
}

${ }^{* 4}$ Graduate School of Engineering, Mie-University,
1577 Kurimamachiya-cho, Tsu-shi, Mie, 514-8507 Japan

\begin{abstract}
The jet pump generally needs a long throat to mix the driving and induced fluids and transfer the momentum of driving fluid to induced fluid. Simultaneously, the energy loses when the fluids flow through the long throat because the friction loss occurs inside of the throat wall. Therefore, it is known that the throat length largely affects the jet pump efficiency. In this study, to obtain fundamental knowledge of the effect of surface roughness in the throat on jet pump performance, experimental studies were performed for a typical single nozzle jet pump using water at room temperature. It was revealed that surface roughness located nearer the throat inlet had a greatest effect on the jet pump efficiency because the local skin friction coefficient nearest the throat inlet is the largest. The best efficiency and its flow rate ratio decrease linearly as surface roughness increases. The frictional resistance coefficient in the throat for each roughness is made clear by fitting a one-dimensional theoretical prediction equation to the experimental results.
\end{abstract}

Key Words : Jet Pump, Efficiency, Throat, Surface Roughness, Flow Resistance

\section{1. 緒 論}

ジェットポンプは,ノズルから高流速で噴射される 駆動流体と周囲から吸引される被駆動流体とを混合し 駆動流体のもつ運動量を被駆動流体に伝え圧力を回復 させるために, 一般に適切な長さをもつスロートが必 要である. 一方でスロートはその長さのため, スロー 卜内部の流体は内面の摩擦抵抗を受けエネルギーを損 失している筒所であり,これがジェットポンプ効率に 及ぼす影響が大きいことが知られている(1).

沸騰水形原子炉用ジェットポンプについては, これ まで効率の向上を目的に, 最適なスロート長さの検討 がなされてきた. 過去の文献からは, スロート長さは 被駆動水と混合しながら広がっていくノズルからの噴 流がスロート壁面に当たるように選定した長さが最適 と考える場合 ${ }^{(2)}$ や，スロート軸方向の壁面上での全圧 が最大となる長さを最適と考える場合(3) が挙げられ

\footnotetext{
* 原稿受付 2006 年 1 月 20 日.

*1 正員, 三重大学大学院工学研究科( 514-8507 津市栗真町 屋町 1577).

*2 正員, (株) 東芝 ( 235-8523 横浜市磯子区新杉田町 8) [現： 北海道大学大学院工学研究科( $\mathbf{E}$ 060-8628 札幌市北区 138)].

*3 中部電力 (株) ( 461-8680 名古屋市東区東新町 1)。

E-mail : shako@ mach.mie-u.ac.jp
}

る.これらの結果, 典型的な 1 本ノズルの沸騰水形原 子炉用ジェットポンプの場合, スロート長さはその口 径の 8 から 12 倍(2)(3) と報告されており, ジェットポ ンプ全長に占める割合がかなり大きいものとなってい る.

ただし，このジェットポンプ効率への影響の大きい スロートについては, これまで内面が滑面であること が前提であった。

しかし沸騰水形原子炉用ジェットポンプでは, 長期 間にわたる連続的な使用によって, 冷却水中に溶出し た配管材等の $\mathrm{Cr}$ や Fe および被ばく低減のために注 入される $\mathrm{Zn}$ の金属イオンが静電気力により酸化物と なってジェットポンプのスロート内表面へクラッドと してはん点状に付着する現象が見られる.クラッドが スロート内面に付着すると, 表面粗さが増加するため, ジェットポンプの性能が影響を受け低下するが,これ までに定量的な検討は行われていない.

著者らは先に, 本研究での実験装置と同一の装置を 用いノズル・スロート形状の影響がジェットポンプの 混合過程と性能に及ぼす影響を明らかにした ${ }^{(4)}$.

本研究では, 実機の典型的な 1 本ノズルのジェット ポンプについて, スロート内面に付着したクラッドを 洗浄によって除去しその性能を回復させる場合に効果 
的な洗浄箇所を特定することを，すなわちスロート内 面の粗面の軸方向位置および表面粗さ (粗度) がジェッ トポンプの性能に及ぽす影響を実験的に明らかにする ことを目的にした。

さらに, 効率の低下量からクラッド付着の程度を評 価するための知見を得るために，スロート内面の粗さ の変化による効率の低下量を実験的に検討した。

また，実験結果をジェットポンプ特性の理論式(5)に あてはめ, スロート内面の粗さの変化 (粗度) と一般的 な管摩擦係数との関係を明らかにした。

\section{2. おもな 記 号}

$A$ : 断面積 $\mathrm{m}^{2}$

$C_{f}$ : 局所摩擦抵抗係数

$C_{l}$ : 等価摩擦長さ係数

$D:$ 内径 $\mathrm{m}$

$K:$ 抵抗係数

$k_{e}:$ 等価粗さ $\mu \mathrm{m}$

$L:$ 長さ $\mathrm{m}$

$M:$ 流量比 $=Q_{s} / Q_{n}$

$N$ : 圧力比 $=\left(\bar{P}_{d}-\bar{P}_{s}\right) /\left(\bar{P}_{n}-\bar{P}_{d}\right)$

$P$ : 圧力 $\mathrm{Pa}$

$\bar{P}$ : 全圧 $=P+\frac{1}{2} \rho V^{2} \mathrm{~Pa}$

$Q$ : 流量 $\mathrm{m}^{3} / \mathrm{s}$

$R:$ 面積比 $=A_{n} / A_{t}$

$R e$ :レイノルズ数 $=V \times D / \nu$

$V:$ 平均速度 $=Q / A \mathrm{~m} / \mathrm{s}$

$x$ : スロート入ロからの距離 $\mathrm{m}$

$\eta$ : ジェットポンプ効率 $=M \times N$

$\lambda$ : 管摩擦係数

$\nu$ : 水の動粘性係数 $\mathrm{m}^{2} / \mathrm{s}$

$\rho$ : 密度 $\mathrm{kg} / \mathrm{m}^{3}$

添字

$b$ : 最高効率点

$d:$ ディフューザ出口

hs : 流体的に滑面

$n:$ 駆動水ノズル

$r:$ 粗面

$s$ : 被駆動水側スロート入口

$t:$ スロート

$t i ：$ スロート直管部入口

to : スロート直管部出口

\section{3. 実験装置と方法}

$3 \cdot 1$ 実験装置 図 1 に, 実験装置の概略を示す。

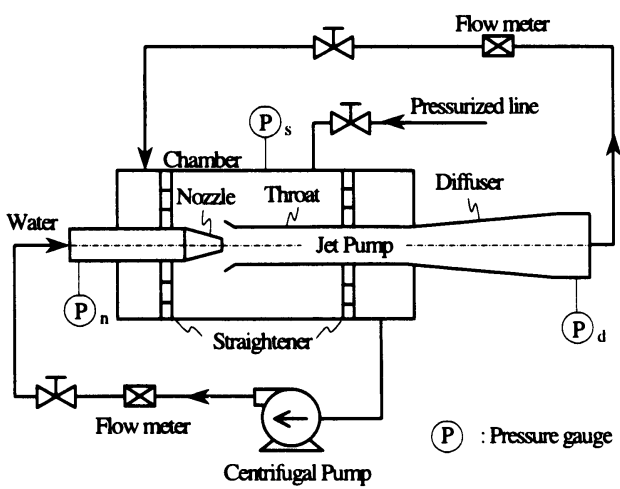

Fig. 1 Experimental set-up of jet pump performance tests

なお，本装置は実機の $1 / 5$ スケールモデルである．遠 心ポンプによって加圧された常温水は電磁流量計を通 ってチャンバ内に設置されたジェットポンプのノズル 部からベルマウス形状のスロート入口に駆動流体とし て噴出される.

チャンバ内部の一部の流体は被駆動流体としてスロ 一ト内へ誘引, 加速され, 駆動流体と被駆動流体が混 合される．混合した流体はディフューザで圧力が回復 し, ジェットポンプから吐出される. 吐出流体は電磁 流量計を通って, チャンバに戻り, 再び駆動流体およ び被駆動流体として循環される。チャンバ内部はジェ ットポンプでのキャビテーションの発生を抑えるため に, 水道水圧で $P_{s} \fallingdotseq 0.35 \mathrm{MPa}$ に加圧され，キャビテ ーションが発生しない高レイノルズ数条件(ノズルレ イノルズ数 $R e_{n}=V_{n} \times D_{n} / \nu=4.8 \times 10^{5}, Q_{n}=6.5 \times$ $\left.10^{-3} \mathrm{~m}^{3} / \mathrm{s}\right)$ で, 吐出し流量 $Q_{d}$ を弁によって調整し流 量比 $M=0.5 \sim 1.8$ (スロートレイノルズ数 $R e_{t}=V_{t} \times$ $D_{t} / \nu=(3.5 \sim 6.6) \times 10^{5}, V_{t}$ : スロートにおける駆動 流量と被駆動流量を混合した流量に対する平均流速) の範囲で圧力 $P_{n}, P_{s}, P_{d}$ を測定して, ジェットポン プ効率 $\eta$ を求めた。

図 2 に, ジェットポンプのノズル部とスロート部の 形状を示す.ノズル断面は円形の先細りノズルで, 出 口の内径は $D_{n}=17 \mathrm{~mm}$, スロートは長さ $L_{t}=430$ $\mathrm{mm}$, 内径 $D_{t}=35 \mathrm{~mm}$ の直管である(4). ノズル出口 端とベルマウス端の距離は実機に準じ零とした。ま た，スロート内面の粗い箇所の例を斜線部で示す.

本研究では, スロート内面の粗さは市販の研磨布紙 をエポキシ樹脂の接着剤によって内面に張り付けるこ とで付加した。

粗面の位置は研磨布紙の張付け位置を変えること で, またスロート内面の粗さは粗さの異なる研磨布紙 


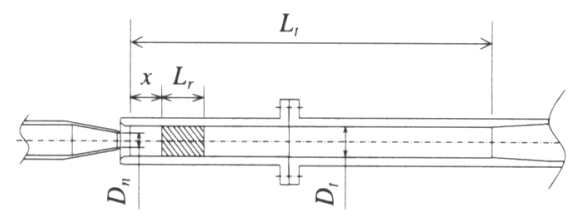

Fig. 2 Configuration of jet pump nozzle and throat

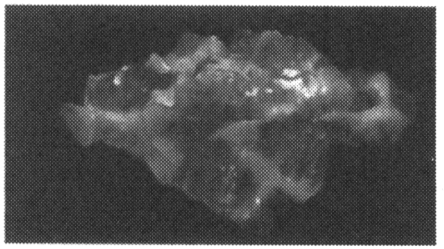

(a) Coated abrasive grain size of P 150

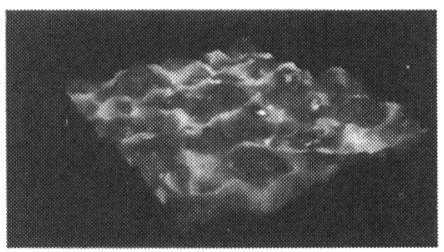

(b) Coated abrasive grain size of P 240

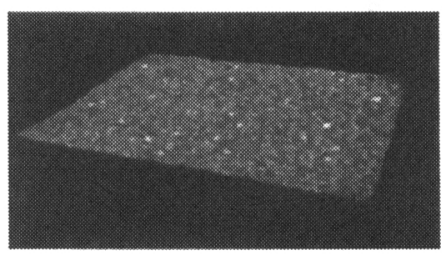

(c) Coated abrasive grain size of P 1200

Fig. 3 3-D surface profile of coated abrasives

を付け替えることで変化させた。

$3 \cdot 2$ 粗面の位置と表面粗さ (粗度) スロート内 面の粗面の位置 (おおよその)がジェットポンプの性能 に及ぼす影響を明らかにするため，その影響が大きい と思われる被駆動流体の加速領域のそれぞれ $x / L_{t}=$ $0 \sim 0.12, x / L_{t}=0.20 \sim 0.31, x / L_{t}=0.31 \sim 0.43$ の 位 置に研磨布紙 (長さ $L_{r}=50 \mathrm{~mm}$ ) を付け替え粗面とし た。また，比較評価のために参考としてディフューザ 入口部についても検討した。 なお,この際の研磨布紙 には市販の P 150 (ISO および JIS 規格に基づく)を用 いた。これに加え, スロート内面の粗さ変化(粗度)の 影響を検討するため, P 240, P 1200 の合計 3 種を用 いた.

供試研磨布紙の表面粗さ計による表面粗さ (peak to peak)の測定結果は, P 150 は $92 \mu \mathrm{mP}-\mathrm{P}$, P 240 は 61 $\mu \mathrm{mP}-\mathrm{P}, \mathrm{P} 1200$ は $10 \mu \mathrm{mP}-\mathrm{P}$ であった.ここで, 規格 上の粒度分布 $50 \%$ の粒子径はP 150 は $98 \pm 8 \mu \mathrm{m}$, $\mathrm{P} 240$ は $58.5 \pm 2.0 \mu \mathrm{m}, \mathrm{P} 1200$ は $15.3 \pm 1.0 \mu \mathrm{m}$ と規 格化されている。これより粒度分布 $50 \%$ の粒子径の 規格值は表面粗さの測定結果 (peak to peak) とほぼ 一致することがわかる。

図 3 に, 研磨布紙の表面形状について光学式による 三次元拡大写真を示す。粒子の一部は接着剂に埋もれ ているが, 粒子がすきまなく張り付いており一様に密 であるようすがわかる。したがって, 本実験で用いる 研磨布紙はニクラーゼの砂状粗面に相当していると考 えられるので，この粒度分布 $50 \%$ の粒子径の值をその まま等価粗さ $k_{e}$ として扱うこととする。

一方，研磨布紙を張り付けていないアクリル製のス ロート内面を滑面と定義し，その等価粗さは引抜管と 同じ $k_{e}=1.5 \mu \mathrm{m}$ と仮定する.

したがって, 使用した 3 種の粗面の相対粗さはそれ ぞれ $k_{e} / D_{t}=0.0028 \pm 0.0002,0.0017 \pm 0.0001$, $0.0004 \pm 0.00003$ で, 滑面の相対粗さは $k_{e} / D_{t}=$ 0.00004 である。

なお，いずれの研磨布紙も試験時間に相当する水中 で膨潤せず初期状態を維持していることを寸法および 粗さの再検查で確認している.

なお，沸騰水形原子炉用ジェットポンプにおける実 際のクラッド付着による表面粗さについては, 放射線 下での水中作業などのため測定が現実的でないことか らこれまでに知見がないが,このことに起因するジェ ツトポンプの効率低下については報告されている.

\section{4. 結果と考察}

$4 \cdot 1$ 粗面の位置の影響図 4 に, 研磨布紙を張 り付けた位置, 寸なわち粗面の位置がジェットポンプ の効率 $\eta$ に及湾す影響を示す。なお，相対粗さは $k_{e} / D_{t}=0.0028$ (P 150)である.

図 5 に, 最高効率点における効率比 $\eta_{b} / \eta_{b, h s}\left(\eta_{b, h s}\right.$ は 滑面に打けるジェットポンプ最高効率) と流量比 $M_{b}$ との関係を示す。ジェットポンプ効率は流量比 $M$ が 大きい領域ほど粗面としたことの影響を受けて大きく 低下寸る。なお,ディフューザについてはスロートと 比べ粗面としたことの影響は小さい.

また, 滑面の場合と比べて, 最高効率点における効 率比 $\eta_{b} / \eta_{b, h s}$ と $M_{b}$ はともに粗面の位置がスロート入 口に近いほど低下する。

ところで, 滑面のスロートの場合, スロート内部の 壁面近傍の速度分布の測定結果から求めた局所摩擦抵 抗係数 $C_{f}$ はスロートの出口に向かっていったん減少 


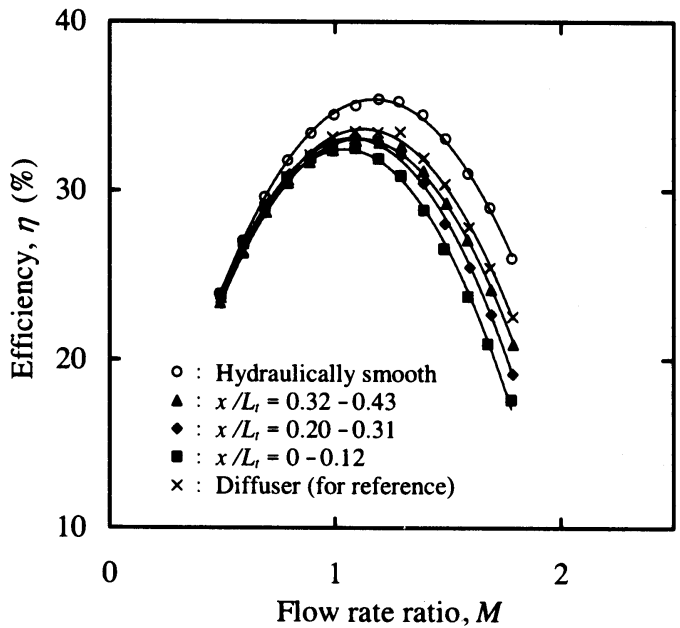

Fig. 4 Effect of rough location on jet pump performance (Relative roughness, $k_{e} / D_{t}=0.0028$ )

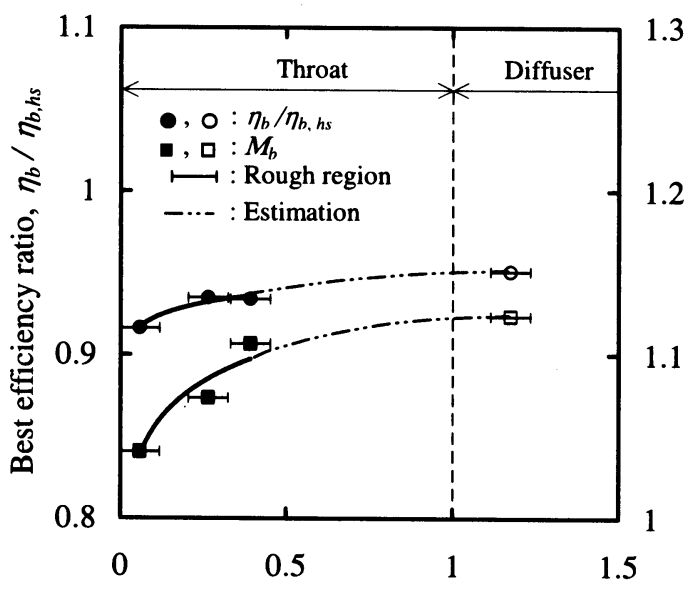

Rough location, $x / L_{t}$

Fig. 5 Effect of rough location on the best efficiency (Relative roughness, $k_{e} / D_{t}=0.0028$ )

しその後乱流境界層へと遷移して増加する傾向があ $る^{(4)}$. この $C_{f}$ の傾向と粗面の位置の影響の実験結果 との比較から, $C_{f}$ が大きい位置と粗面の影響の大き い位置がほほ一致していることがわかった。このため $C_{f}$ が大きいスロート出口においても粗面の影響を大 きく受けることが推測される.

本実験では, 粗面がスロート入口に近いほどジェッ トポンプ効率に影響を及ほすことがわかった。また, スロート出口においても効率に影響を及ぼすことが推 測された。

したがって, 付着したクラッドを洗浄によって除去

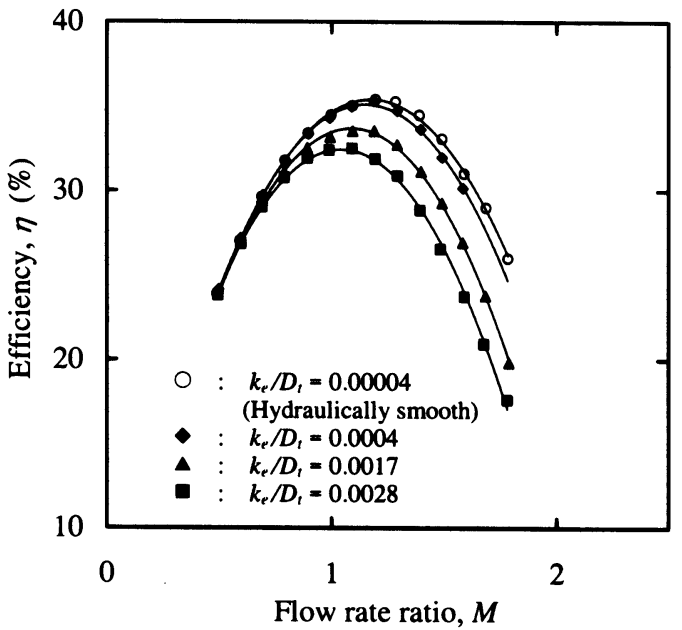

Fig. 6 Effect of relative roughness on jet pump performance (Rough location, $x / L_{t}=0 \sim 0.12$ )

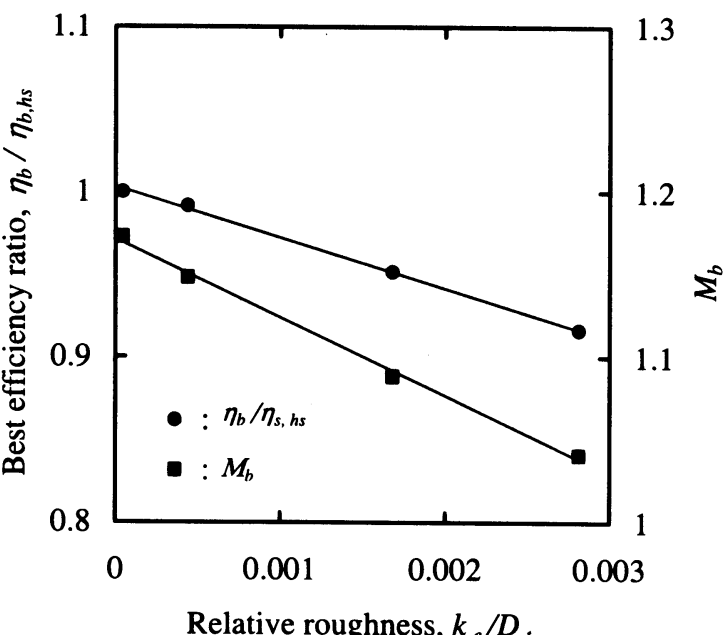

Fig. 7 Effect of relative roughness on the best efficiency (Rough location, $x / L_{t}=0 \sim 0.12$ )

し性能を回復させる場合の効果的な洗浄箇所は，おも にスロート入口部と考えられる.

$4 \cdot 2$ 表面粗さ(粗度)の影響 図 6 に, 張り付け た研磨布紙の表面粗さの差異, すなわち相対粗さ $k_{e} / D_{t}$ の変化がジェットポンプ効率に及ぼす影響を示 す. 粗面の位置は, その影響を最も受けるスロート入 ロに最も近い位置 $x / L_{t}=0 \sim 0.12$ とした. 図 4 の場 合と同様に, ジェットポンプ効率は流量比 $M$ が大き い領域ほど粗面としたことの影響を受け大きく低下す る.

図 7 に, 最高効率点における効率比 $\eta_{b} / \eta_{b, h s}$ と流量 
比 $M_{b}$ との関係を示す. 最高効率点における効率 $\eta_{b}$ と流量比 $M_{b}$ は相対粗さ $k_{e} / D_{t}$ が増加するほど滑面に 比べて低下し，ともに相対粗さ $k_{e} / D_{t}$ の増加により線 形的に低下する.

本研究では, ジェットポンプの効率低下に影響を及 ほすスロート入口の表面粗さと効率の低下量との関係 を実験的に明らかにした。このため, 実機の運転中に 効率または流量比の低下が測定された場合に, クラッ ド付着の程度を定量的に評価するための知見が得られ たと考えられる。

$4 \cdot 3$ 理論的予測 スロート入口近傍の内面の粗 さがジェットポンプ性能に及ほす影響に関し,ジェッ トポンプ特性の理論式(5)を使って, 実験に使用した相 対粗さごとの摩擦損失係数 $\lambda$ を検討した.

ジェットポンプ特性の理論式は, ジェットポンプの 流路に対し，エネルギー保存則および運動量保存則, 連続の式を適用することで導出される.

ノズル部の駆動流体および被駆動流体, ディフュー ザ内のエネルギー保存式はそれぞれ，

$$
\begin{aligned}
& \bar{P}_{n}-\bar{P}_{t i}=K_{n} \frac{\rho V_{n}^{2}}{2} \\
& \bar{P}_{s}-\bar{P}_{t i}=K_{s} \frac{\rho V_{s}^{2}}{2} . \\
& \bar{P}_{t o}-\bar{P}_{d}=K_{d} \frac{\rho V_{t}^{2}}{2}
\end{aligned}
$$

と表され, 駆動流体と被駆動流体の混合するスロート 内部については運動量保存則を適用し,

$$
P_{t o}-P_{t i}=\rho\left[R V_{n}^{2}+(l-R) V_{s}^{2}-V_{t}^{2}\right]-K_{t} \frac{\rho V_{t}^{2}}{2}
$$

と表される。なお, 式（4)では運動量はスロート内部 で完全に交換が完了するものとした。

被駆動流体の吸込部，およびスロート内部の平均流 速 $V$ は，連続の式よりそれぞれ $V_{n}$ を用いて，

$$
\begin{aligned}
& V_{s}=\left(\frac{R}{l-R}\right) M \times V_{n} \\
& V_{t}=R(l+M) \times V_{n} .
\end{aligned}
$$

と表される。

これらよりジェットポンプ特性の理論式は,

$$
\begin{aligned}
\eta=M \times \frac{\bar{P}_{d}-\bar{P}_{s}}{\bar{P}_{n}-\bar{P}_{d}} \\
=-M \times \frac{\left[\begin{array}{c}
\left(l+K_{s}\right)\left(\frac{R M}{l-R}\right)^{2}-2 R-\frac{2 R^{2} M^{2}}{l-R} \\
+R^{2}(l+M)^{2}\left(l+K_{t}+K_{d}\right)
\end{array}\right]}{\left[\begin{array}{c}
\left(l+K_{n}\right)-2 R-\frac{2 R^{2} M^{2}}{l-R} \\
+R^{2}(l+M)^{2}\left(l+K_{t}+K_{d}\right)
\end{array}\right]}
\end{aligned}
$$

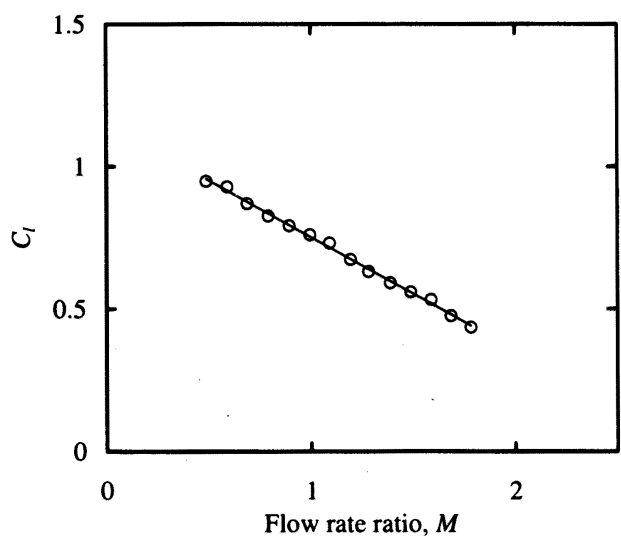

Fig. $8 C_{l}$ distribution for hydraulically smooth jet pump

と表される.

ここで, 各部の抵抗係数は, 実験結果よりノズルは $K_{n}=0.01$, ディフューザは $K_{d}=0.16$, ベルマウスに ついては各種文献(6) に基づき $K_{s}=0.02$ と与えられ る.

ところで, 十分に発達した乱流の直管の抵抗係数 $K$ は一般的に $K=\lambda \times(L / D)$ で表される。そこで，ス口 一トの抵抗係数 $K_{t}$ についてはこれを参考にして,

$$
K_{t}=\lambda \times \frac{C_{l} L_{t}}{D_{t}}
$$

と定義する.

ここで, 配管長さ $L$ としてスロート長さ $L_{t}$ を用い るが，この長さには被駆動流体の加速領域も含まれ， 十分発達した乱流とは明らかに異なる。そこで本研究 では等価摩擦長さ係数 $C_{l}$ を定義し, 式 (8) に示すと おりスロート長さ $L_{t}$ に対し，これを用いて十分発達 した乱流との違いを配管長さで補正することとした。

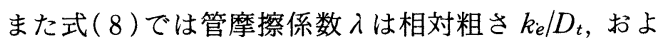
びスロートのレイノルズ数 $\operatorname{Re}_{t}\left(=V_{t} \times D_{t} / \nu\right)$ を用い $\tau$, Moody 線図 ${ }^{(7)} の$ Colebrook $の$ 公式,

$$
\frac{1}{\sqrt{\lambda}}=-2 \log \left(\frac{k_{e} / D_{t}}{3.7}+\frac{2.5 l}{R e_{t} \sqrt{\lambda}}\right)
$$

により算出する。

式 (8),（9)を用いて, ジェットポンプ特性の理論 式 ( 7 )が滑面のジェットポンプの実験結果に一致する 等価摩擦長さ係数 $C_{l}$ を調査した。

図 8 に, $C_{l}$ と $M$ との関係を示す. $C_{l}$ は, 流量比 $M$ の増加とともに直線的に減少する.これは $M$ の增 加とともに, 十分に発達した乱流の直管の抵抗係数と の偏差が拡大することを示す.

本研究ではこの $C_{l}$ の特性は, ジェットポンプの形 


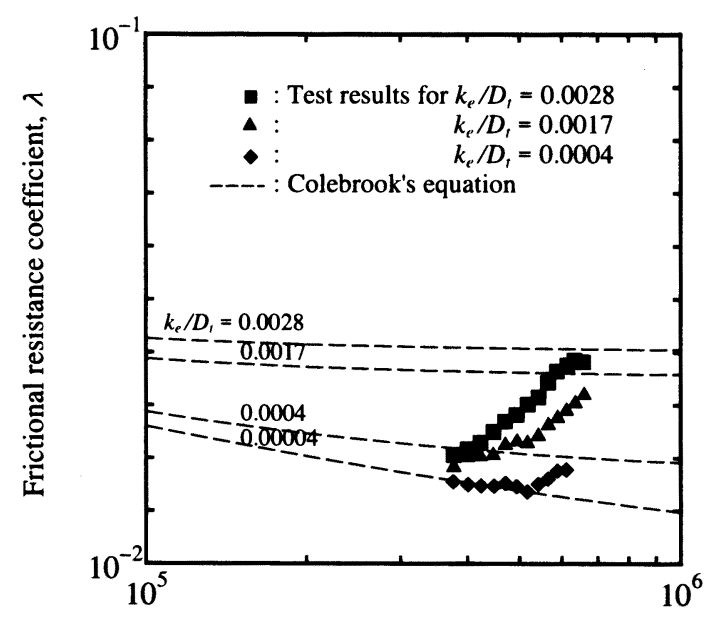

Reynolds number, $\operatorname{Re}_{t}=V_{t} \times D_{t} / v$

Fig. 9 Effect of relative roughness on jet pump throat (Rough location, $x / L_{t}=0 \sim 0.12$ )

状に依存するものとした。

次に, 3 種類のスロート内表面の粗度の影響の実験 結果から, 式( 8$)$ および図 8 の $C_{l}$ から表されるジェ ットポンプ特性の理論式 ( 7 ) が実験結果と一致する管 摩擦係数 $\lambda$ を各相対粗さ $k_{e} / D_{t}$ について調査した。

図 9 に, Moody 線図上に実験結果から算出した管 摩擦係数 $\lambda$ を 3 種類の供試粗面(相対粗さ $k_{e} / D_{t}=$ $0.0028,0.0017,0.0004)$ について示す.

また, 図 9 には供試粗面の相対粗さならびに滑面の 相対粗さ $k_{e} / D_{t}=0.00004$ の 4 種類の場合について Colebrookの公式 (9) から算出される十分に発達し た乱流の速度分布の場合の管摩擦係数 $\lambda$ とレイノル ズ数との関係を破線で示す.

実験結果から算出される 3 種類の相対粗さに対応す る管摩擦係数 $\lambda$ は, 低レイノルズ数領域では相対粗さ $k_{e} / D_{t}$ の影響をほとんど受けずそれぞれ滑面の場合に 近い值を示すが, レイノルズ数の増加とともに破線で 示す Colebrook の公式 (9) から算出される各相対粗 さ $k_{e} / D_{t}$ に対する $\lambda$ に近い值に漸近するのがわかる.

また, ジェットポンプの粗面がスロート入口部の一 部 $\left(x / L_{t}=0 \sim 0.12\right)$ であるにもかかわらず, 高レイノ ルズ数では, スロート全体の相対粗さが増加したこと に等しいことがわかる.

本研究では, 実験結果をジェットポンプ特性理論式 を使って整理し, スロート内面の粗さの変化に対する 管摩擦係数の関係を明らかにした。

\section{5. 結 論}

本研究では, 典型的な 1 本ノズルのジェットポンプ
について，スロート内面に付着するクラッドを洗浄に よって除去し，その性能を回復させる場合の効果的な 洗浄箇所の選定を行うことを目的に, 粗面のスロート の軸方向位置および表面粗さ (粗度)がジェットポンプ の性能に及ぼす影響を実験的に検討した。ささに，効 率の低下量からクラッド付着の程度を評価するための 知見を得るために, スロート内面の粗さの変化による 効率の低下量を実験的に検討した。また，実験結果を ジェットポンプ特性の理論式にあてはめ, スロート内 面の粗さの変化が一般的な管摩擦係数に及ぼす影響を 検討した.

おもな結果は, 以下のようである.

（1）粗面の位置は，スロート入ロに近いほどジェ ットポンプ効率に影響を及ぼし，スロート出ロについ てはその影響が大きいことが推定された，付着するク ラッドを洗浄によって除去し性能を回復させる場合の 効果的な洗浄筒所は，おもにスロートの入口部と考え られる。

（2）スロート内面の粗さの増加により最高効率点 における効率および流量比はともに線形的に低下す る.このことは, 実機で効率の低下量または流量比の 低下量が測定される場合には, クラッド付着の程度を 評価するための知見となる。

（3）実験結果をジェットポンプ特性理論式を使っ て整理し, スロート内面の粗さの変化と一般的な管摩 擦係数の関係を明らかにした。

\section{文献}

(1) Kudirka, A. A. and Gluntz, D. M., Development of Jet Pumps for Boiling Water Reactor Recirculation Systems, Trans. of ASME, J. of Engneering for Power, Vol. 96, Jan. (1974), pp. 7-12.

(2) Nei, H. and Narabayashi, T., Characteristics of Jet Pumps for Nuclear Reactors, Trans. of the Japan Society of Mechanical Engineers, Ser. B, Vol. 60, No. 569 (1994), pp. 194-200.

(3) Oshima, R., Studies on the Optimum Throat Length of the Jet Pumps, Trans. of the Japan Society of Mechani. cal Engineers, Ser. B, Vol. 54, No. 497 (1988), pp. 125130.

(4) Yamazaki, Y. et al., Studies on Mixing Precess and Performance Improvement of Jet Pump, Trans. of the Japan Society of Mechanical Engineers, Series B, Vol. 71, No. 701 (2005), pp. 147-153.

(5) Sanger, N. L., An Experimental Investigation of Several Low-Area-Ration Water Jet Pumps, Trans. of ASME, J. of Basic Engneering, Vol. 92, Mar. (1970), pp. 11-20.

(6) The Japan Society of Mechanical Engineers, ed., Flow resistance of pipe and duct flows, (1979), p. 53, The Japan Society of Mechanical Engineers.

( 7 ) Moody L. F., Friction Factors for Pipe Flow, Trans. of $A S M E$, Vol. 66 (1944), pp. 671-684. 